\title{
ICT, National Policies, and their Impact on Schools and Teachers' Development
}

\author{
Rosa Maria Bottino \\ Consiglio Nazionale delle Ricerche Istituto Tecnologie Didattiche, Via De Marini 6-16149, \\ Genova, Italy, bottino@itd.ge.cnr.it
}

\section{INTRODUCTION}

This paper briefly sketches Italian public policy in promoting the use of ICT (Information and Communication Technologies) in school education (primary and secondary level). It tries to identify aspects that appear to be supporting the development of pedagogically 'sound' approaches to technology, enhanced teaching and learning, as well as some of the problems that are in evidence.

The objective is to contribute to the discussion on the ways in which public policy can facilitate the development of appropriate forms of technology use in school, considering it in the wider perspective of the information society.

\section{ITALIAN POLICY FOR THE DEVELOPMENT OF TECHNOLOGY ENHANCED LEARNING}

For some years the Italian government has put in place programmes to equip educational institutions with the necessary ICT infrastructure and to train teachers.

In 1997 the Ministry of Education launched a Programme for the Development of Educational Technologies (PSTD) having as its main stated goals: the provision of infrastructure to schools (PCs, internet connections, etc.); the improvement of teachers' professional skills in using ICT; the improvement of effectiveness of learning and teaching methods and content; and the promotion of the use of ICT and multimedia tools among students.

The original version of this chapter was revised: The copyright line was incorrect. This has been corrected. The Erratum to this chapter is available at DOI: 10.1007/978-0-387-35701-0_35 
Moreover the Italian government, in line with the eEurope Plan (www.europa.eu), adopted an Action Plan for the Information Technology Society on June 2000 with the aim of further completing and strengthening the educational technologies development programme.

The programme offered funding to individual schools for the creation of equipped laboratories and for organising autonomous basic ICT courses for teachers. A total of 13,300 schools were involved between 1997 and 2001. The situation is quite different from school to school with regard, for example, to school level, school typology, and school geographical location. Table 1 briefly summarises the average current situation regarding technology infrastructure in schools (Fierli, 2002). It can be noted that technological equipment is mainly located in laboratories, and access is seldom available from classrooms.

Table 1. Average situation in Italy regarding technology infrastructure in schools

\begin{tabular}{lll}
\hline School level & PC/students & $\begin{array}{l}\text { Schools with Internet } \\
\text { connections (\%) }\end{array}$ \\
\hline Primary school (age 6-11) & $1 / 50$ & $80 \%$ \\
Lower secondary (age 11-14) & $1 / 25$ & $80 \%$ \\
Upper secondary (age 14-19) & $1 / 10$ (from about $1 / 5$ of & From 100\% of technical \\
& $\begin{array}{l}\text { technical schools to } 1 / 25 \text { of } \\
\text { schools to } 80 \% \text { of lycei }\end{array}$ & \\
\hline
\end{tabular}

As far as teacher training is concerned, the first widespread initiative of the Government was the National Plan for Informatics (launched in 1985). This was a centralized plan for in-service mathematics teacher training whose aim was to provide basic computer science literacy. This training plan was enacted through courses for teachers in which traditional lessons alternated with computer practice. The method used was a 'pull-down' one (i.e. the training programme is operated through trainers who are in-service teachers specifically trained for this purpose).

These training initiatives had been funded by the Ministry, but their organisation and content had been left to schools. Between 1997 and 2001, 43,300 refresher courses for teachers were organised as a consequence.

Currently it can be said that approximately half of the Italian primary and secondary school teachers have been involved in training initiatives related to the use of information and multimedia technologies. Quality and depth of training have been very variable.

Now the Ministry has launched and financed the development of on-line services for training support. On-line training at present involves approximately 60,000 teachers.

For the next year a new initiative (funded with UMTS license incomes) will involve 180,000 teachers. This initiative will provide 12 hours of training for each teacher (six hours face to face and six hours online). 
In addition to the great effort of the Government in providing schools with ICT infrastructure and teachers with a basic knowledge in ICT, the Ministry has recently promoted initiatives to support the use of ICT in classroom practice. Some projects have been launched to provide teachers with examples of practice in which technology has been used to support the teaching of discipline topics. Such projects (SET projects, INDIRE documentation of experiences) are aimed at publishing on the Internet didactical itineraries (both at primary and secondary school level) on curricular topics integrating ICT. These projects have had positive aspects (such as the involvement of both teachers and educational researchers in the implementation of the educational itineraries) and have represented interesting experiences for the teachers directly involved in the work, but still they have not had a significant impact on a wider basis.

\section{IMPACT ON SCHOOL EDUCATION}

Despite the efforts made in the field of training and in the equipping of schools, to date the results at the school level are still relatively limited. There is not a wide integration of ICT use as tools to enhance teaching and learning in curricular topics.

Even when the use of ICT, though with differing modes and characteristics, enters into teaching practice, one often observes purely superficial changes that do not impact upon the effective renewal of the syllabuses and methods, i.e. the modification of the methodological approaches, the content and relational dynamics in classes and schools, and the organisational aspects within schools (Bottino \& Furinghetti, 1999). This situation is not substantially different from that in other European countries (Mallon, 2002).

One can observe that the government programme for the development of educational technologies has achieved significant results in providing schools with technology infrastructure and a considerable number of teachers with ICT basic skills. Nevertheless this has not led directly to an improvement of teaching and learning methods and to a change in approaching discipline subjects. A direct relationship cannot be established between provision of infrastructure and ICT training, and the effective pedagogical use of technology in schools. This last goal is less clearly supported by governmental polices and needs a careful consideration of related difficulties and possible interventions. 
Difficulties that can be shown are of a different nature and can be related both to technical and structural problems and to more general organisational and pedagogical aspects'(Prometeus Position Paper, 2001).

It is a fact that the resistance on the part of many teachers to using ICT in class can be ascribed to technical and structural problems such as, for example, the lack of technical personnel to help manage laboratories, the fact that the substantial time dedicated to preparation of materials and lessons which integrate technology use is not acknowledged in teachers' current work time, and the limits imposed by the overall scholastic system (the ever increasing number of subjects and topics present in syllabuses, the limited time available, the question of individual assessment of students, etc.). The often poor quality of educational software available, with a predominance on the market, especially at primary and secondary school levels, of substantially drill and practice systems, have often reduced the initial enthusiasm of teachers towards the use of technology as a means to renew and improve teaching methods.

Moreover, ICT training often has been confined to the development of product-related skills rather then being aimed at the promotion of more general and critical skills (such as, for example, how to choose among different products, how to develop capacities of finding proper and meaningful information on the web, how to use available products in discipline teaching, etc.).

Nevertheless, even if all the preceding considerations are true, one will miss the point if he or she does not consider that, from a pedagogical point of view, it is pointless to make ICT based tools available if the educational strategies and the activities the learners engage in are not suitably revised. Technology can influence learning by fundamentally changing both the content of a subject and the way in which that content can be taught and learnt.

It is widely recognised that the professional development of teachers in the field of ICT has to be carried out through the development of competencies both in their use and in their integration in discipline teaching. In the initial pioneering period the influence of the "computer anxiety/appeal' has strongly pushed towards the necessity of teachers acquiring a practical knowledge about computers and computer related products. After a number of experimentations, it has been recognised that to confine teachers' knowledge only to this level is not fruitful and could be dangerous.

These considerations bring with them the problem of the policies that can be enacted to promote such changes. 


\section{FROM 'TECHNOLOGY PUSH' TO 'DEMAND PULL'}

Policies should move from technology push (i.e. actions that are driven by the necessity to make the technology available and usable) to 'demand-pull' (i.e. actions that are driven by users' needs and pedagogical opportunities).

Politicians should be convinced that ICT is not, by itself, an easy and cheap solution to educational problems. The successful introduction of ICT in schools is determined not only by money invested, but also by a change of mental habit.

Until fairly recently the use of ICT tools such as word-processing, graphics packages, database and spreadsheet applications, has often been proposed as evidence of technology uptake and integration into learning and teaching. While many worthwhile uses have been made of these tools, their integration has largely been as an optional addendum to an unchanging traditional teaching environment.

When reflecting on the design and use of technology for education we need to consider the whole teaching and learning situation; not only how technology can be applied but also the needs of the teachers who will use it, the ways in which it will be used, the curriculum objectives, the social context and the way in which learning is organised.

This means that consideration needs to be given to the definition of meaningful practices through which technology can be used effectively. The design itself of educational technology should include examples of meaningful pedagogical processes based on a widespread consensus derived from appropriate pedagogical research. These considerations can have an impact on policies to promote technology enhanced learning.

The next stage for policies should be to concentrate on the provision of a network for disseminating good practices, research results, discussions, and exchange of ideas and perspectives in order to promote a true synergy among the different actors. In other words, it is necessary to intervene in the school context to promote a paradigm shift in ways of looking at teaching and learning processes, considering the innovations and needs brought about by new technologies not only in schools but in the society as a whole.

Even if it is not possible to define a single strategy for promoting such change, some general indications can be outlined:

- Promoting co-operation among teachers, researchers in educational technology and in discipline subjects, administrators, trainers, parents, etc. This could be done by increasing investments in research and development and in the creation of new learning environments for working together. In particular, it should be considered that any 
partnership for change in the relationship between research and classroom activity must include teachers as equal partners. As a matter of fact, what has not yet taken place sufficiently is the co-operation of experts across the diverse disciplines in research and practice networks. The essential enabling mechanism for such networks is the implementation of mutual exchange and verification of practicable results. As an example: educational concepts of IT support for education have to undergo technological implementation, and technological concepts of IT support for education have to undergo educational verification.

- Promoting the collection, documentation, and diffusion of good practice examples. There is a mounting interest in aspects related not only to software design, but also to the definition of ways of use suited to exploiting software features in order to accomplish meaningful teaching and learning activities. It is therefore not enough to establish collections of best practice, or to codify knowledge about e-learning, since the knowledge will only be of use to teachers and learners who are new to elearning if it is made suitable for people in their position, rather than for experts. Moreover, the study of models for effective dissemination of successful pilot projects is needed to ensure teachers are aware of the potential of technology-supported learning.

- Promoting curricular change, shifting the focus from knowledge as a set of content to knowledge as an integration of processes and skills. The changing global context due to the impact of ICT is redefining the type of literacy and skills that are needed. Such skills are not only technical (e.g. how to access and use distributed and continuously changing information), but also cognitive (i.e. how to integrate different knowledge), relational (i.e. how to foster interpersonal capacities, responsibility, co-operation, adaptability, flexibility, etc.), and concerning high-order thinking (such as problem solving, creative thinking, decision making etc.). The crucial importance of new skills has started to receive considerable political interest throughout Europe. Several actions have been launched by the European Commission such as the Action Plan for skills and mobility (European Commission, 2002) and the establishment of the European ICT Skills Monitoring Group (2002).

- Rethinking teachers' training as a life-long learning perspective. Even if the aim of training, at a first level, has been to give teachers sufficient levels of confidence, competence and flexibility in the use of new technologies, this is not enough to significantly affect the process of innovation. Teachers need to be given the training to operate effectively in ICT-rich environments and the 'space' within their school based 
work, to take advantage of the potential it offers. The integration of ICT use into pre and in-service programmes for teachers will need to support them not in the automation of traditional process, but rather to use ICT to support active engagement, problem solving, group learning, interactions, feedback and connections with the 'outside' world. Training should be based on planning and reflection on classroom practice and potential new practice, including a reflection of their own roles as teachers and of learners' roles. Some recent UNESCO reports can be considered as reference in this regard (see UNESCO 2001, 2002).

\section{REFERENCES}

Bottino, R. M. \& Furinghetti, F. (1999). Mathematics teachers, new technologies and professional development: Opportunities and problems. In N. Ellerton (Ed.), Mathematics Teachers Development: International Perspectives (pp. 1-11). Australia: Meridian Press.

Bottino, R. M., Kearney, N., Lefrere, P. \& Lindquist, K. (Eds) (2001). Position Paper. Open Consultation Process. PROMETEUS Report. Retrieved from http://www.prometeus.org/ E_gatekeeper.cfm?FileID $=148$

European Commission (2002). Retrieved from http://europa.eu.int/comm/ employment_social/news/2002/feb/ap_en.html

European ICT Skills Monitoring Group (2002). Retrieved from http://europa.eu.int/comm/ enterprise/ict/policy/ict-skills.htm

Fierli, M. (2002). Le Tecnologie Didattiche Nella Scuola: Stato Dell'arte e Prospettive, Italian Ministry of Education, Atti multimediali del Convegno. TED2002, Genova, maintained by D. Persico, L. Ferlino, G. Olimpo, M. Tavella \& C. Tirendi. Retrieved from http://www.ted-online.it/atti2002/index.htm

Mallon, M. (Ed.) (2002). Addressing Change in the Role of the Teacher in ICT Based Learning: Uptake and Integration Considerations. PROMETEUS Report. Retrieved from http://www.prometeus.org

UNESCO (2001). Report on: Teacher Education through Distance Learning: Technology, Curriculum, Evaluation and Cost. Retrieved from http://unesdoc.unesco.org/images/ 0012/001253/125396e.pdf

UNESCO (2002). Report on: Teacher Education Guidelines: Using Open and Distance Learning. Retrieved from htpp://unesdoc.unesco.org/images/0012/001253/125396e.pdf 